\title{
Rumen-protected choline for dairy cows: the in situ evaluation of a commercial source and literature evaluation of effects on performance and interactions between methionine and choline metabolism
}

\author{
Frank BRÜSEMEISTER*, Karl-Heinz SÜDEKUM** \\ Institute of Animal Nutrition and Physiology, Christian-Albrechts-University, Kiel, Germany
}

(Received 13 May 2005 - Accepted 20 December 2005)

\begin{abstract}
The interactions were investigated between methionine and choline metabolism due to interchangeable methyl groups. Feeding trials on dairy cows with choline administration were re-evaluated with a focus on methionine balance and the possible effects of supplementary choline on methionine metabolism. In addition, in situ ruminal stability was estimated for a commercial choline supplement. We examined six experiments that included 11 dietary treatments. The Cornell net carbohydrate and protein system was used to estimate nutrient supply and requirements as well as methionine balance; further methionine supply was assessed according to the ideal protein concept. The re-evaluation of feeding trials confirmed the positive effects of supplementary abomasally available choline on milk yield and health of dairy cows. Although these effects were mainly attributed to an elevated export of triglycerides from the liver, beneficial effects may be further caused by an exoneration of methionine metabolism by sparing S-adenosylmethionine. Therefore, the effects on milk yield or other response variables of additional, abomasally available choline could serve as an indicator of methyl group deficiency and thus methionine shortage. Since from theoretical considerations the demand for methyl groups in dairy cows is related to the stage of lactation, requirements for methionine and methyl groups should be taken as separate entities and the latter should be expressed in relation to energy balance or days in milk. Our in situ data indicate that Reashure choline ${ }^{\circledR}$ was effectively protected against ruminal degradation because at least $600 \mathrm{~g} \cdot \mathrm{kg}^{-1}$ of choline were in a rumen-protected form. In conclusion, (I) supplementary choline may improve the yield of dairy cows by elevating the export of triglycerides from the liver and by sparing methionine as a methyl donor, and (II) the demand for methyl groups still lacks adequate consideration in the design of diets for dairy cows.
\end{abstract}

dairy cow / requirement / methionine / choline / methyl group

\footnotetext{
* Present address: Pioneer Hi-Bred Northern Europe GmbH, Apensener Str. 198, 21614 Buxtehude, Germany.

** Corresponding author: ksue@itz.uni-bonn.de

Present address: Institute of Animal Science, University of Bonn, Endenicher Allee 15, 53115 Bonn, Germany.
} 
Résumé - Apport de choline protégée aux vaches laitières : évaluation in situ d'une source commerciale, et évaluation bibliographique de ses effets sur les performances et sur le métabolisme de la méthionine. Des essais dans lesquels de la choline avait été administrée à des vaches laitières ont été réévalués en portant une attention particulière au bilan de la méthionine et aux effets de la choline apportée en supplément sur le métabolisme de la méthionine. De plus, la stabilité dans le rumen d'un supplément commercial de choline a été évaluée in situ. Six essais incluant 11 traitements alimentaires ont été étudiés. Le système d'alimentation énergétique et azoté de Cornell a été utilisé pour estimer l'apport et le besoin de nutriments, et le bilan de la méthionine. En outre, l'apport de méthionine a été évalué selon le concept de la protéine idéale. La réévaluation des essais d'alimentation a confirmé l'effet positif de l'apport de choline disponible dans la caillette sur la quantité de lait produite et la santé des vaches laitières. Bien que ces effets aient été principalement attribués à une sécrétion accrue de triglycérides par le foie, des effets bénéfiques peuvent aussi être provoqués par une épargne de S-adénosylméthionine, donneuse de groupements méthyle. Les effets de la choline supplémentaire disponible dans la caillette ont pu servir comme indicateurs d'insuffisance de groupements méthyle et, ainsi, d'apport de méthionine insuffisant. Puisque, à partir de considérations théoriques, le besoin en groupements méthyle chez des vaches laitières est lié au stade de lactation, les besoins en méthionine et en groupements méthyle devraient être considérés comme des entités séparées, et ces derniers devraient être exprimés par rapport au bilan énergétique ou au stade de lactation. Nos données in situ ont montré qu'au moins $60 \%$ de la choline Reashure ${ }^{\circledR}$ apportée était effectivement protégée contre la dégradation dans le rumen. En conclusion : (i) l'apport de choline supplémentaire peut améliorer la production des vaches laitières en accroissant la sécrétion de triglycérides par le foie et en épargnant la méthionine en tant que donneuse de groupements méthyle; (ii) le besoin de groupements méthyle n'est toujours pas suffisamment pris en compte dans le rationnement des vaches laitières.

vache laitière / besoin / méthionine / choline / groupement méthyle

\section{INTRODUCTION}

Several metabolic disorders in dairy cows occur especially during the transition period when cows may undergo a severe negative energy balance. With the onset of lactation, feed intake increases slowly, whereas nutrient and energy requirements increase rapidly. Adipose tissue is mobilised and the plasma levels of non-esterified fatty acids (NEFA) are elevated. The NEFA are utilised by several tissues but are transported to the liver as well. If uptake into the liver exceeds conversion (e.g., oxidation or synthesis of ketone bodies) and export (in the form of triglycerides (TG) via very-low-density lipoproteins (VLDL)), excess lipids are stored in the liver as TG [4]. Since several metabolic disturbances and diseases are associated with a severe negative energy balance, an optimal feeding strategy and diet composition during the transition period appear to be the best prevention of health disturbances and associated decline of milk yield. Additional approaches frequently include feed additives such as glucogenic precursors, fatty acids and others (see [19]).

Recent research indicated that one of these feed additives, rumen-protected choline (RPC), might increase VLDL synthesis in the liver. Choline is a constituent of phosphatidylcholine (trivial name: lecithin), which is inevitably involved in VLDL synthesis [19]. On the contrary to that in non-ruminant animals, virtually no lecithin is synthesised from feed-based choline in ruminants: choline from feedstuffs is degraded extensively in the rumen [2, $31,32]$. Lecithin in ruminants is usually synthesised by threefold transfer of methyl groups from S-adenosylmethionine (AdoMet) onto phosphatidylethanolamine $[22,34]$. Hence, RPC may serve to spare cellular methionine (Met) as the methyl donor as it delivers choline for the synthesis of lecithin.

The aims of the present study were to review current knowledge on 
interrelationships between Met and choline metabolism (i.e. synthesis and degradation of both, choline and methionine) and to re-evaluate the Met supply of diets used in published feeding trials with supplementary choline. Since only few experiments have been conducted, a detailed statistical evaluation was not possible; data were sufficient only to evaluate the Met supply of diets for dairy cows in general. Additionally, an in situ trial was conducted to assess the effectiveness of choline protection against ruminal degradation in a commercial RPC source.

\section{MATERIALS AND METHODS}

\subsection{Re-evaluation of feeding trials with supplementary choline}

\subsubsection{Input data}

Diets ( $\mathrm{n}=11$ treatment means) from feeding experiments $(n=6)$ were evaluated for balance of metabolisable energy (ME), metabolisable protein (MP) and absorbed Met and for absorbed Met as a proportion of MP. Only Holstein cows were used in the analysed experiments (Tab. I); cows were mostly multiparous (as far as reported). The stage of lactation at the beginning of the experiments was very heterogeneous and ranged from $28 \mathrm{~d}$ prior to calving to about $150 \mathrm{~d}$ in milk. Choline was supplemented as RPC or infused postruminally into the abomasum or duodenum. We did not consider further a short-term experiment by Grummer et al. [14] and experiments in which choline was fed as unprotected choline chloride $[2,11,31]$.

Concerning the chemical composition of diets and animal performance data, average milk yield was $32.3 \mathrm{~kg} \cdot \mathrm{d}^{-1}$ (standard deviation (SD) 5.7) with average concentrations of milk protein and fat of $32 \mathrm{~g} \cdot \mathrm{kg}^{-1}$ (SD 2) and $36 \mathrm{~g} \cdot \mathrm{kg}^{-1}$ (SD 5). Hence, $4 \%$ fat-corrected milk (FCM) yield was $29.5 \mathrm{~kg} \cdot \mathrm{d}^{-1}$ (SD 8.1). Dry matter (DM) intake (DMI) averaged $20.4 \mathrm{~kg}$ per day (SD
2.5), and the diets were based upon maize products: the proportion of maize, fed as forage plus concentrate, ranged from 490 to $900 \mathrm{~g} \cdot \mathrm{kg}^{-1}$ of DMI. Maize silage either constituted the sole forage (7 treatments) or was fed as a mixture with others (mostly lucerne as silage or hay). Concentrates accounted for 380 to $700 \mathrm{~g} \cdot \mathrm{kg}^{-1} \mathrm{DMI}$ and mainly consisted of maize grain, with soybean meal or maize gluten feed as the major protein supplements. The energy density (net energy for lactation) of the diets averaged $7.3 \mathrm{MJ} \cdot \mathrm{kg}^{-1} \mathrm{DM}$ (SD 0.3) and the mean crude protein concentration was $157 \mathrm{~g} \cdot \mathrm{kg}^{-1} \mathrm{DM}$ (SD 18) with an average of $387 \mathrm{~g} \cdot \mathrm{kg}^{-1}$ crude protein (SD 37) as ruminally undegraded protein.

\subsubsection{Calculations}

Metabolisable energy, MP and Met balances were calculated using the Cornell net carbohydrate and protein system (CNCPS [12]). Data of ME, MP and Met balances are reported as the ratio of excess or shortage of supply to requirements. The feeds listed in the publications were matched with feeds from feeding model libraries. Crude nutrient concentrations of feedstuffs were modified to reflect actual, published dietary concentrations when available. Although the output of the CNCPS may not reflect the actual data for each diet, it provides reasonable overall estimates. The supply of Met was assessed using two concepts. First, digestible Met at $25 \mathrm{~g} \cdot \mathrm{kg}^{-1}$ of MP as recommended by the ideal protein concept $[6,27]$ was used. In the output of the CNCPS, this number is reported as the percent of absorbed Met of MP. Second, the Met balance computed by the CNCPS was used as a comparative value.

\subsection{In situ trial}

\subsubsection{Animals and diet}

Three six-year-old German Red Pied steers were used, weighing $940 \mathrm{~kg}$ on 


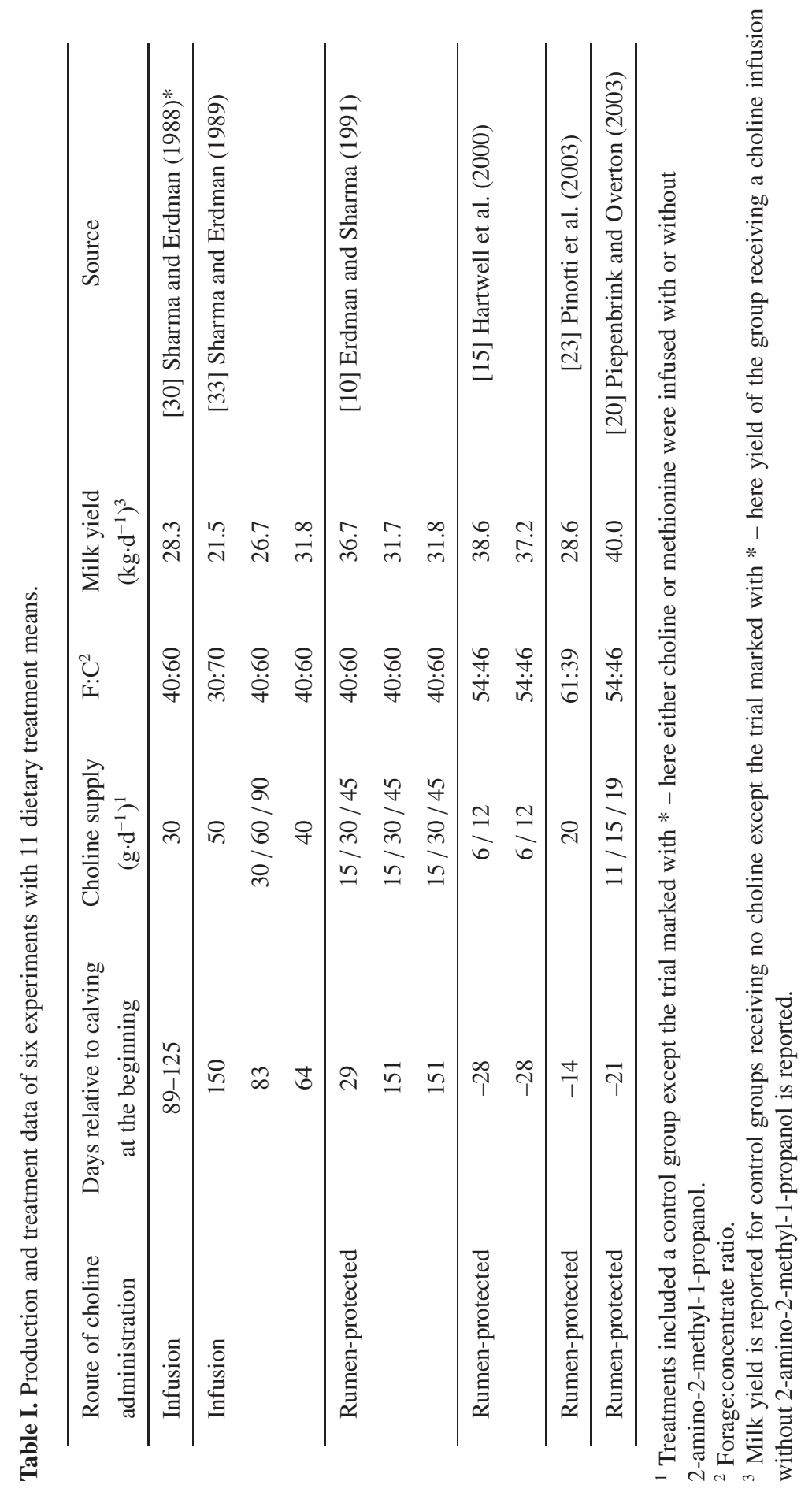


average. Each steer was fitted with a $10 \mathrm{~cm}$ internal diameter ruminal cannula (Model 1C, Bar Diamond, Parma, ID, USA) and housed in individual tie stalls on rubber mattresses with free access to water. The steers were offered a diet consisting of grass silage, wheat straw, and mixed concentrates in the ratio $\left(\mathrm{g} \cdot \mathrm{kg}^{-1} \mathrm{DM}\right)$ of 560:140:300 in two equal portions at 07:00 and 19:00 hours. The DMI corresponded to approximately $110 \%$ of the estimated ME requirements for maintenance [1].

\subsubsection{In situ procedure}

Ruminal DM and choline disappearance of a commercial RPC source ${ }^{1}$ was determined using an in situ procedure described in detail elsewhere [29]. Briefly, polyester bags $(5 \mathrm{~cm} \times 10 \mathrm{~cm}, \mathrm{R} 510$, Ankom Technology, Macedon, NY, USA) with a pore size of $50 \mu \mathrm{m}$ were used. Duplicate samples of RPC were incubated in the rumens of the three steers, and about $1.3 \mathrm{~g}$ of fresh matter were placed in each bag. The bags were stored frozen $\left(-18^{\circ} \mathrm{C}\right)$ until the start of incubation.

Before incubation, each bag was sealed with a commercial cable binder $(10 \mathrm{~cm}$ length); then, the bags were clamped to a cylindrical anchor weight (800 g), which was tied to an $80 \mathrm{~cm}$ long main line outside the fistula. Prior to incubation, the bags were soaked in warm water $\left(40{ }^{\circ} \mathrm{C}\right)$ for 10 minutes. All bags were inserted into the ventral sac of the rumen at 07:00 hours directly before feeding. Incubation periods were $2,4,6,8,16,24,48,72$ and 336 hours. After ruminal incubation, the bags were immediately immersed in ice water to minimise microbial activity. The bags were then washed with cold water in a washing machine for 20 minutes in order to remove feed particles adhering to

${ }^{1}$ Reashure choline ${ }^{\circledR}$; Balchem Inc., Slate Hill, NY, USA. the bag surface. Water was exchanged five times during washing, and no spin cycle was used.

Zero time disappearance values (0 hours) were obtained by washing pre-soaked, unincubated bags in a similar fashion. The bags were freeze-dried before chemical analysis.

\subsubsection{Laboratory analysis}

The DM of feeds consumed by the steers and that of RPC and freeze-dried residues after ruminal incubation were determined by oven-drying at $105{ }^{\circ} \mathrm{C}$ overnight. The RPC and the residues after ruminal incubation were analysed for choline contents according to the method of Takayama et al. [36]. Choline was oxidised to betaine by choline oxidase with the simultaneous production of hydrogen peroxide, which by oxidation couples 4-aminoantipyrine and phenol to yield a chromatogen with a maximum absorbance at $\lambda=500 \mathrm{~nm}$. Choline chloride (approx. 99\%; C7017, Sigma-Aldrich Chemie $\mathrm{GmbH}$, Munich, Germany) was used as a standard. For RPC, the method of Takayama et al. [36] had to be modified to overcome the fatty acid encapsulation such that the sample was heated to about $60{ }^{\circ} \mathrm{C}$ before further processing.

\section{RESULTS}

\subsection{Re-evaluation of feeding trials with supplementary choline}

Data of MP and ME balance as well as Met supply are reported in Table II. In only two of six trials (three dietary treatments) energy supply was lower than the requirements, MP was deficient in three trials (four dietary treatments), and the Met balance calculated by the CNCPS was negative in two trials (three dietary treatments). 


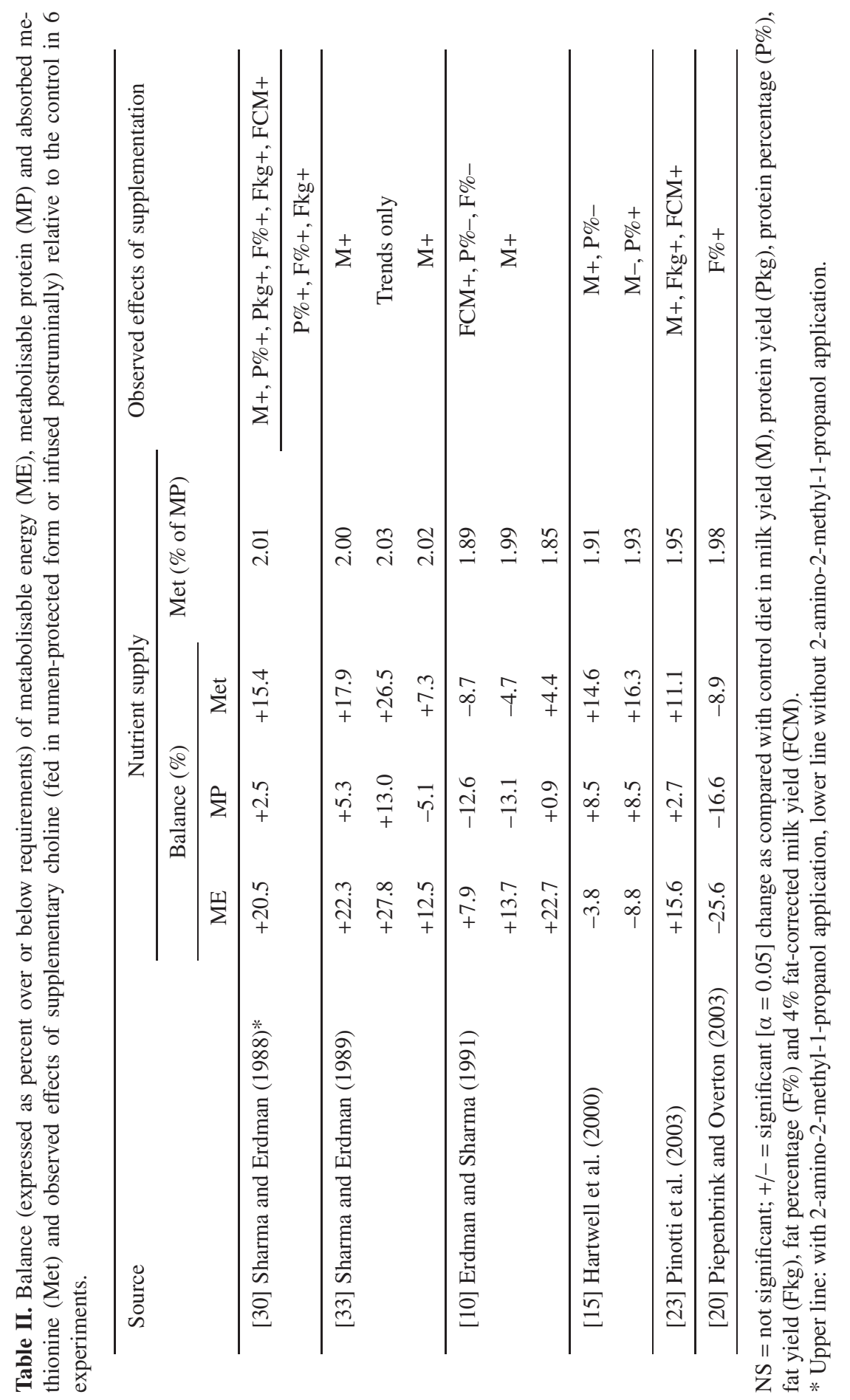


On the contrary, the percentage of Met was less than $21 \mathrm{~g} \cdot \mathrm{kg}^{-1}$ of MP for all dietary treatments and thus below the threshold formulated by the ideal protein concept.

The effects of choline supplementation on performance variables varied. For 10 treatments, significant effects were observed, mostly increased milk yield $(n=6)$, sometimes accompanied by increased contents or yields of protein ( $\mathrm{n}=3$ and 1$)$ or fat $(\mathrm{n}=3$ and 3$)$; decreased yields were observed in three cases. For the remaining treatment, only performance tended to be higher than the control.

\subsection{In situ trial}

The average choline content of RPC was $234 \mathrm{~g} \cdot \mathrm{kg}^{-1}$. This value corresponded well with that given by the manufacturer $\left(250 \mathrm{~g} \cdot \mathrm{kg}^{-1}\right)$. Ruminal DM and choline stability of RPC are reported in Figure 1.

The DM losses remained below $100 \mathrm{~g} \cdot \mathrm{kg}^{-1}$ at all incubation times: Washout losses (0-hour disappearance value) were about $36 \mathrm{~g} \cdot \mathrm{kg}^{-1}$ and additional losses occurred at the beginning of the incubation. At longer periods of incubation total DM disappearance values decreased. Regarding choline stability of RPC, a rapid initial disappearance $(0 \mathrm{~h})$ of choline occurred, after which no considerable further disappearance was observed. Overall, choline disappearance values never exceeded $400 \mathrm{~g} \cdot \mathrm{kg}^{-1}$ of the amount incubated irrespective of the duration of incubation.

\section{DISCUSSION}

\subsection{Re-evaluation of feeding trials with supplementary choline}

The beginning of lactation is one of the most crucial periods in the lactation cycle of dairy cows. Since some excellent reviews have been recently published concerning the role of lecithin [22] and liver metabolism of dairy cows during this time $[4,19]$ only a brief account will be given here.

At the beginning of the lactation cycle, the plasma level of NEFA originating from the mobilisation of adipose tissue is elevated - mainly due to a negative energy balance (see [19]). If the uptake of NEFA into the liver exceeds the liver utilisation (oxidation and synthesis of ketone bodies) and export of fatty acids from the liver in the form of VLDL, excess TG are stored in hepatocytes (see [4]). An accumulation of TG (i.e., fatty liver, hepatic lipidosis) may lead to an impaired capacity of the liver for gluconeogenesis [5,35] and would result in a reduced performance. In general, a hepatic lipidosis is associated with a decreased health status (see [4]). Hence, efforts should focus on minimising storage of TG in the liver. An optimal nutrition serves to decrease the magnitude of the negative energy balance but cannot solve the problem of excess uptake of TG into the liver in high-yielding dairy cows. In general, VLDL secretion of hepatocytes of ruminants is much lower than that of non-ruminants, and the secretion rate appears to be much lower than the rate of hepatic TG synthesis (see [13]). Therefore, it is advisable to avoid any limitation of VLDL synthesis. The rate limiting steps of VLDL synthesis are not entirely clear yet; especially the synthesis of lecithin and apolipoproteins may be limiting ([3], see [19]). While the influence of the availability of apolipoproteins is largely speculative to date, the influence of lecithin, first shown by Yao and Vance [37] in trials with rats, was confirmed in several experiments with dairy cows (see $[19,22])$. Since dietary choline is degraded virtually completely in the rumen, lecithin may be quantitatively synthesised endogenously in ruminants by threefold transfer of methyl groups from AdoMet onto phosphatidylethanolamine. 


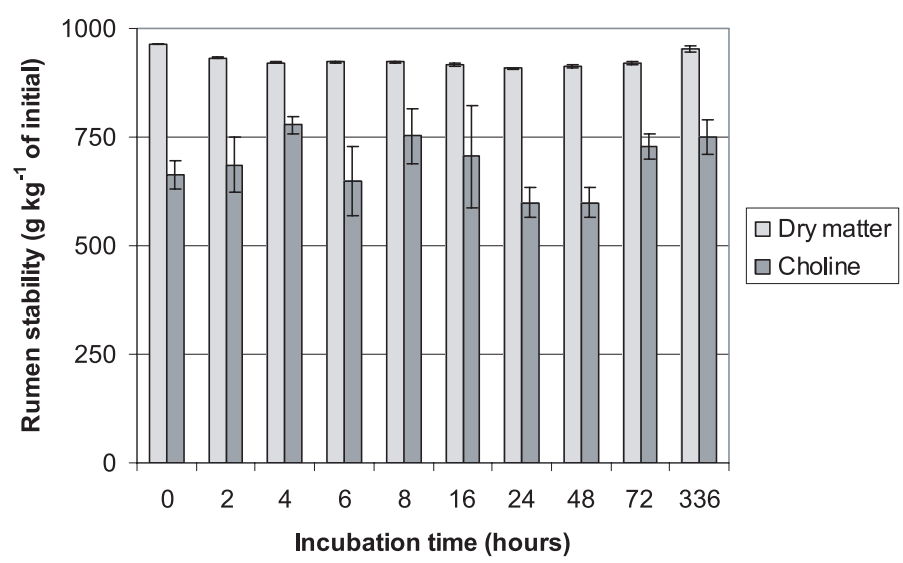

Figure 1. Ruminal dry matter and choline stability of a commercial source of rumen-protected choline (RPC, based on 6 observations ( 3 steers with two replicates per steer) per incubation time). Vertical bars indicate the standard error.

To date most of the potential application of choline in the nutrition of transition dairy cows has focused on its role in lipid metabolism [19]. Pinotti et al. [22] presumed that the extra demand during lactation for methyl groups for the synthesis of lecithin and other compounds may be met by enhanced de novo synthesis of methyl groups via the tetrahydrofolate system. A recent trial validated the hypothesis [24], however, the quantitative importance of this pathway still needs to be investigated. Emmanuel and Kennelly [9], however, reported that in lactating goats more than one fourth of total Met $\left(280 \mathrm{~g} \cdot \mathrm{kg}^{-1}\right)$ is utilised for choline synthesis. Hence, the rate of lecithin synthesis may be limited due to a deficient supply of Met as assumed by some workers who reported that supplementary Met affects the hepatic VLDL balance $[8,25]$. Thereby, milk yield of dairy cows may decline: export of TG is depressed by insufficient supply of methyl groups from AdoMet for the synthesis of lecithin, and the rate of gluconeogenesis is lowered due to an accumulation of TG in liver hepatocytes. Since as much as half of Met requirements may be met through remethylisation of homocys- teine [7], it seems reasonable to assume that a deficient methyl group supply from AdoMet also indicates a shortage of Met.

Positive effects of supplementary choline were observed with 10 of the 11 dietary treatments that were re-evaluated in this study. Based on the ideal protein approach, all diets were deficient in Met supply $\left(<25 \mathrm{~g} \cdot \mathrm{kg}^{-1}\right.$ of MP), whereas the Met balance calculated by the CNCPS was negative for only three dietary treatments. It seems probable that the concept of the ideal protein reflects the methyl group supply from AdoMet more appropriately than the Met balance does. The amino acid sub-model of the CNCPS uses a factorial approach for determining the daily requirements for and supply of absorbed amino acids [18], whereas Met requirements in the ideal protein concept were derived from dose-response trials with predominantly early-lactation cows. Since an elevated demand for methyl groups likely occurs in the transition period when the plasma level of NEFA increases, the latter approach appears more adequate. Additionally, in a comparison of systems for the protein quality of diets for dairy cows [21], the ideal protein 
concept most accurately predicted milk protein percentages and production, and was superior to other models such as the CNCPS.

In three of the 10 dietary treatments with significant effects of choline supplementation on animal performance, elevated protein contents or yields were also observed. Those effects, likely due to elevated casein contents, were frequently observed in trials with supplementary abomasally available Met and lysine (see [28]). Hence, at least with these treatments, supplementary choline presumably exonerated Met metabolism, leading to elevated protein contents or yields. Several mechanisms may be involved with such a response. First, RPC may serve to spare methyl groups and hence AdoMet as the methyl group donor usually necessary for the synthesis of lecithin. Second, RPC may serve as the methyl group donor for remethylisation of homocysteine via its metabolite betaine (see $[22,26]$ ). Third, betaine may also spare Met by substituting for AdoMet as the methyl group donor in some metabolic processes [26]. The latter two mechanisms are still hypothetical. Trials investigating this objective in general are rare, and to our knowledge, no study on dairy cows has been published so far.

Based on the concept of the ideal protein, all diets re-evaluated in this study were deficient in Met supply, and this was in line with earlier experiments that showed that Met can become first limiting in maize silage-based diets [25]. Thus and from theoretical considerations regarding the transition period - it seems reasonable to assume that a shortage of supply of methyl groups from AdoMet is common in transition dairy cows - at least, if diets are based on maize. Therefore, the question arises as to how the demand for methyl groups can best be met - either supplying extra RPC or extra Met?

Met plays a crucial role in mammalian metabolism: as an essential amino acid, a precursor of cysteine biosynthesis and the key intermediate in methyl group transfer [17]. Thus, in case of Met shortage, rumenprotected Met seems to be a more appropriate supplement, since RPC may only serve to spare methyl groups. Moreover, a direct exoneration of Met metabolism by RPC in dairy cows has not been clearly shown to date. On the contrary, supplementary RPC appears to be the better choice, if an elevated lecithin synthesis and elevated VLDL synthesis in hepatocytes during the transition period is the primary goal. It appears reasonable to conclude that demand for methyl groups for the synthesis of lecithin will vary depending on the metabolic and energetic status of the dairy cow. Hence, it seems useful to separate the demand for methyl groups from Met requirements and to express the demand for methyl groups in relation to the actual energy balance. Since the energy balance of dairy cows especially depends on the stage of lactation, the demand for methyl groups could be expressed related to days in milk as an approximation of overall energy balance.

In order to verify this assumption, trials should be conducted with cows classified by energy balance and (or) days in milk, and diets should be based on maize. Since the demand for methyl groups is presumably best met by supplementary choline, RPC should be used in doseresponse experiments. Milk yield and Met supply should be considered as other factors of influence. Furthermore, possible interactions with methyl groups delivered by de novo synthesis via the tetrahydrofolate system should not be ruled out.

\subsection{In situ trial}

Ruminal dry matter losses of RPC were low, relatively constant, and never exceeded $100 \mathrm{~g} \cdot \mathrm{kg}^{-1}$. These numbers were in good agreement with the results of an 
in vitro trial by Kung et al. [16]. The decline of losses at incubation times longer than 24 hours is somewhat surprising and might be related to microbial infiltration of bags. Ruminal choline stability showed fluctuations that might be related to variations in the analysis of choline contents of RPC because of a possibly uneven distribution of choline within samples of RPC. Despite the greater variance of choline contents of RPC, it can be stated that ruminal choline disappearance never exceeded $400 \mathrm{~g} \cdot \mathrm{kg}^{-1}$ and most of this disappearance occurred as washout loss; no trend towards progressing disappearance at longer incubation periods was observed. This again confirms the in vitro data of Kung et al. [16].

\section{CONCLUSION}

Supplementary RPC showed positive effects on health and/or yield in several feeding trials on dairy cows, which is mainly attributed to an elevated synthesis of VLDL in the liver. Data possibly indicate that supplementary RPC exonerates Met metabolism due to interchangeable methyl groups. The extent of the beneficial effects of supplementary RPC presumably depends on the energy balance of the dairy cow. Vice versa, supplementary rumen-protected Met may have positive impacts on choline metabolism. Both assumptions, however, remain hypothetical to date because no experiments on dairy cows have been published investigating this mutual influence. Because beneficial effects of supplementary RPC, mainly attributed to the supply of additional methyl groups, have been frequently observed, we conclude that the demand for methyl groups in dairy cows to date lacks adequate consideration. If a deficiency of methyl groups in dairy cows is likely to occur, RPC appears to be a good choice for supplementation; its encapsulation technique prevented around $600 \mathrm{~g} \cdot \mathrm{kg}^{-1}$ of its choline from ruminal degradation. Since this protection lingers at slow dilution rates, it is applicable as well in the transition period, when low DMI are observed frequently.

In conclusion, further nutrition experiments are required for a better understanding of the interrelationship between Met and choline metabolism and for a quantification of the demand for methyl groups of dairy cows especially during the transition period.

\section{ACKNOWLEDGEMENTS}

Partial financial support was provided by Handelsgesellschaft für Spezialfuttermittel $\mathrm{mbH}$, Hamburg, Germany (Dr. T. Engellandt) and Hamburger Leistungsfutter $\mathrm{GmbH}$, Hamburg, Germany (Dr. J. Kemna). We thank Prof. $\mathrm{S}$. Wolffram for inspiring and constructive discussions during the course of this study, W. Kühl for excellent assistance in laboratory analyses and Dr. M. Looff for helpful comments on earlier versions of this manuscript.

\section{REFERENCES}

[1] AFRC, Energy and Protein Requirements of Ruminants. An Advisory Manual Prepared by the AFRC Technical Committee on Responses to Nutrients, CAB INTERNATIONAL, Wallingford, 1993.

[2] Atkins K.B., Erdman R.A., Vandersall J.H., Dietary choline effects on milk yield and duodenal flow in dairy cattle, J. Dairy Sci. 71 (1988) 109-116.

[3] Bernabucci U., Ronchi B., Basiricò L., Pirazzi D., Rueca F., Lacetera N., Nardone A., Abundance of mRNA of apolipoprotein $\mathrm{B}_{100}$, apolipoprotein $\mathrm{E}$, and microsomal triglyceride transfer protein in liver from periparturient dairy cows, J. Dairy Sci. 87 (2004) 2881-2888.

[4] Bobe G., Young J.W., Beitz D.C., Invited review: pathology, etiology, prevention, and treatment of fatty liver in dairy cows, J. Dairy Sci. 87 (2004) 3105-3124.

[5] Cadórniga-Valiño C., Grummer R.R., Armentano L.E., Donkin S.S., Bertics S.J., 
Effects of fatty acids and hormones on fatty acid metabolism and gluconeogenesis in bovine hepatocytes, J. Dairy Sci. 80 (1997) 646-656.

[6] Doepel L., Pacheco D., Kennelly J.J., Hanigan M.D., López I.F., Lapierre H., Milk protein synthesis as a function of amino acid supply, J. Dairy Sci. 87 (2004) 1279-1297.

[7] Donkin S.S., Rumen-protected choline: potential for improving health and production in dairy cows, Tri-State Nutrition Conference, Ft. Wayne, IN, 2002, pp. 55-65.

[8] Durand D., Chilliard Y., Bauchart D., Effects of lysine and methionine on in vivo hepatic secretion of VLDL in the high yielding dairy cow, J. Dairy Sci. 75 (Suppl. 1) (1992) 75.

[9] Emmanuel B., Kennelly J.J., Kinetics of methionine and choline and their incorporation into plasma lipids and milk components in lactating goats, J. Dairy Sci. 67 (1984) 19121918.

[10] Erdman R.A., Sharma B.K., Effect of rumenprotected choline in lactating dairy cows, J. Dairy Sci. 74 (1991) 1641-1647.

[11] Erdman R.A., Shaver R.D., Vandersall J.H., Dietary choline for the lactating dairy cow: possible effects on milk fat synthesis, J. Dairy Sci. 67 (1984) 410-415.

[12] Fox D.G., Tedeschi L.O., Tylutki T.P., Russell J.B., Van Amburgh M.E., Chase L.E., Pell A.N., Overton T.R., The Cornell net carbohydrate and protein system model for evaluating herd nutrition and nutrient excretion, Anim. Feed Sci. Tech. 112 (2004) 29-78.

[13] Grummer R.R., Etiology of lipid-related metabolic disorders in periparturient dairy cows, J. Dairy Sci. 76 (1993) 3882-3896.

[14] Grummer R.R., Armentano L.E., Marcus M.S., Lactation response to short-term abomasal infusion of choline, inositol, and soy lecithin, J. Dairy Sci. 70 (1987) 2518-2524.

[15] Hartwell J.R., Cecava M.J., Donkin S.S., Impact of rumen undegradable protein and rumen-protected choline on intake, peripartum liver triglyceride, plasma metabolites and milk production in transition dairy cows, J. Dairy Sci. 83 (2000) 2907-2917.

[16] Kung L., Putnam D.E., Garrett J.E., Comparison of commercially available rumen-stable choline products, [Online] http://www. balchem.com / images / pdfs / TR20031.pdf [Access date: 31.08.2005].

[17] Lobley G.E., Connell A., Revell D., The importance of transmethylreactions to methio- nine metabolism in sheep: effects of supplementation with creatine and choline, Brit. J. Nutr. 75 (1996) 47-56.

[18] O’Connor J.D., Sniffen C.J., Fox D.G., Chalupa W., A net carbohydrate and protein system for evaluating cattle diets: IV. Predicting amino acid adequacy, J. Anim. Sci. 71 (1993) 1298-1311.

[19] Overton T.R., Waldron M.R., Nutritional management of transition dairy cows: strategies to optimize metabolic health, J. Dairy Sci. 87 (E Suppl.) (2004) 105-119.

[20] Piepenbrink M.S., Overton T.R., Liver metabolism and production of cows fed increasing amounts of rumen-protected choline during the periparturient period, J. Dairy Sci. 86 (2003) 1722-1733.

[21] Piepenbrink M.S., Schingoethe D.J., Brouk M.J., Stegeman G.A., Systems to evaluate the protein quality of diets fed to lactating cows, J. Dairy Sci. 81 (1998) 1046-1061.

[22] Pinotti L., Baldi A., Dell'Orto V., Comparative mammalian choline metabolism with emphasis on the high-yielding dairy cow, Nutr. Res. Rev. 15 (2002) 315-331.

[23] Pinotti L., Baldi A., Politis I., Rebucci R., Sangalli L., Dell'Orto V., Rumen-protected choline administration to transition cows: Effect on milk production and vitamin E status, J. Vet. Med. A 50 (2003) 18-21.

[24] Pinotti L., Campagnoli A., Sangalli L., Rebucci R., Dell'Orto V., Baldi A., Metabolism in periparturient dairy cows fed rumen-protected choline, J. Anim. Feed Sci. 13 (Suppl. 1) (2004) 551-554.

[25] Pisulewski P.M., Rulquin H., Peyraud J.L., Vérité R., Lactational and systemic responses of dairy cows to postruminal infusions of increasing amounts of methionine, J. Dairy Sci. 79 (1996) 1781-1791.

[26] Puchala R., Sahlu T., Herselmann M.J., Davis J.J., Hart S.P., Effect of betaine on plasma amino acids in Alpine and Angora kids, J. Anim. Sci. 72 (Suppl. 1) (1994) 77.

[27] Rulquin H., Pisulewski P.M., Vérité R., Guinard J., Milk production and composition as a function of postruminal lysine and methionine supply: a nutrient-response approach, Livest. Prod. Sci. 37 (1993) 69-90.

[28] Schwab C.G., Rumen-protected amino acids for dairy cattle: progress towards determining lysine and methionine requirements, Anim. Feed Sci. Tech. 59 (1996) 87-101.

[29] Shannak S., Südekum K.-H., Susenbeth A., Estimating ruminal crude protein 
degradation with in situ and chemical fractionation procedures, Anim. Feed Sci. Tech. 85 (2000) 195-214.

[30] Sharma B.K., Erdman R.A., Abomasal infusion of choline and methionine with or without 2-amino-2-methyl-1-propanol for lactating dairy cows, J. Dairy Sci. 71 (1988) 24062411.

[31] Sharma B.K., Erdman R.A., Effects of high amounts of dietary choline supplementation on duodenal choline flow and production responses in dairy cows, J. Dairy Sci. 71 (1988) 2670-2676.

[32] Sharma B.K., Erdman R.A., In vitro degradation of choline from selected feedstuffs and choline supplements, J. Dairy Sci. 72 (1989) 2772-2776.

[33] Sharma B.K., Erdman R.A., Effects of dietary and abomasally infused choline on milk production responses of lactating dairy cows, J. Nutr. 119 (1989) 248-254.

[34] Snoswell A.M., Xue G., Methyl group metabolism in sheep, Comp. Biochem. Phys. B 88 (1987) 383-394.

[35] Strang B.D., Bertics S.J., Grummer R.R., Armentano L.E., Effect of long-chain fatty acids on triglyceride accumulation, gluconeogenesis, and ureagenesis in bovine hepatocytes, J. Dairy Sci. 81 (1998) 728-739.

[36] Takayama M., Itoh S., Nagasaki T., Tanimizu I., A new enzymatic method for determination of serum choline-containing phospholipids, Clin. Chim. Acta 79 (1977) 93-98.

[37] Yao Z., Vance D.E., The active synthesis of phosphatidylcholine is required for very low density lipoprotein secretion from rat hepatocytes, J. Biol. Chem. 263 (1988) 29983004. 